\title{
Thiopentone inhibits beta-adrenergic responses in myocardial tissue
}

\author{
Timothy A. Thurston MD, Babu P. Mathew mS
}

The purpose of this study was to determine the importance of inhibition of beta-adrenergic function in thiopentone-induced myocardial depression. Using an isolated, electrically stimulated rat left atria model, contractile dose-response curves to thiopentone $(200 \mu M, 400 \mu M, 600 \mu M, 800 \mu M)$ were shifted to the right in preparations treated with $10^{-3} \mathrm{M}$ dibutyryl cyclic adenasine monophosphate (cAMP) compared with atria stimulated with $10^{-6} \mathrm{M}$ isoprenaline, demonstrating that inhibition of beta-adrenergic mechanisms by thiopentone is physiologically important. Depression by thiopentone was similar in atria treated with $10^{-5} M$ forskolin compared with preparations stimulated with $10^{-6} \mathrm{M}$ isoprenaline, indicating that thiopentone does not block beta-adrenergic receptors. It is concluded that thiopentone depresses myocardial function by several mechanisms, one of which involves inhibition of the adenyl cyclase cascade. The adenyl cyclase enzyme is a likely site where thiopentone inhibits the system; however, other components of the cascade may also be involved.

L'objectif de cette étude consiste à déterminer linfluence de l'inhibition de l'activité $\beta$-adrénergique sur la dépression myocardique induite par le thiopentone. A l'aide d'un modèle constitué d'une oreillette gauche de rat stimulée électriquement, la relation dose-effet du thiopentone sur la contractilité (200 $\mu M, 400 \mu M, 600 \mu M, 800 \mu M)$ se déplace vers la droite dans des préparations traitées avec de l'adénosine monophosphorique cyclique (cAMP) $10^{-3} \mathrm{M}$ comparativement à des oreillettes stimulées avec de lisoprénaline $10^{-6} \mathrm{M}$, ce qui démontre que

\section{Key words}

ANAESTHETICS, INTRAVENOUS: thiopentone;

HEART: contractility;

SYMPATHETIC NERVOUS SYSTEM: adenyl cyclase, cyclic adenosine monophosphate, forskolin, isoprenaline.

From the Department of Anesthesiology, The University of Texas Medical Branch at Galveston; Galveston, Texas USA.

Address correspondence to: Dr. Timothy A. Thurston,

Department of Anesthesiology, The University of Texas

Medical Branch at Galveston, Galveston, TX 77555 USA.

Accepted for publication 2nd June, 1995. l'inhibition $\beta$-adrénergique provoquée par le thiopentone est physiologiquement importante. La dépression de l'oreillette provoquée par le thiopentone est identique à celle que produit la forskoline $10^{-5} \mathrm{M}$ comparativement à celle de lisoprénaline $10^{-6} \mathrm{M}$, ce qui indique que le thiopentone ninhibe pas les récepteurs $\beta$-adrénergiques. Les auteurs concluent que le thiopentone déprime la fonction myocardique par plusieurs mécanismes qui impliquent linhibition de la cascade de ladényl cyclase. Linhibition du système se produit vraisemblablement au niveau de l'enzyme adényl cyclase; cependant, il est possible que d'autres éléments de la cascade de l'adényl cyclase soient impliqués.

Thiopentone is short-acting barbiturate commonly used to induce general anaesthesia. Undesirable depression of cardiovascular function frequently occurs with the use of this agent. Barbiturates indirectly depress cardiovascular homeostasis by inhibiting central nervous sympathetic outflow and act directly on myocardial tissue by blocking voltage-gated calcium channels. ${ }^{1-4}$ Other possible sites where thiopentone may act to decrease myocardial contractility include sarcolemmal calcium binding sites ${ }^{5}$ and sarcoplasmic reticulum. ${ }^{6}$

Beta $a_{1}$ adrenergic agonists activate myocardial adenyl cyclase, causing a well-described positive inotropic effect. ${ }^{7}$ Beta $_{1}$ adrenergic responses are mediated via external cellular receptors. Attachment of a beta $a_{1}$ adrenergic agonist to its receptor activates the $G$ protein, $G_{s}$ that then combines with adenyl cyclase and increases the activity of the enzyme. In a similar manner, adenosine and acetylcholine bind to cell receptors and activate $G_{i}$ that combines with adenyl cyclase and decreases the enzyme's activity. The function of the myocardial adenyl cyclase system can also be modified by other agents. Forskolin directly interacts with adenyl cyclase to increase the activity of the enzyme. Dibutyryl cyclic adenosine monophosphate (cAMP) is a nonhydrolyzable analogue of cAMP that can cross cell membranes and mediate a positive inotropic response that is unaffected by agents that inhibit adenyl cyclase activity. ${ }^{8}$

The activity of adenyl cyclase from heart, lung, and 
brain membrane preparations is inhibited by barbiturates. ${ }^{9-12}$ Whether barbiturates inhibit the function of the adenyl cyclase cascade in intact cells has not been extensively studied. Massart et al. showed that the TSHstimulated cAMP levels in isolated thyrocytes are reduced by thiopentone, and this phenomenon is associated with decreased production of thyroglobulin and tri-iodothyroxine. ${ }^{13}$ Vasopressin-induced cAMP production in toad urinary bladder and water flow across the bladder membrane are likewise inhibited by phenobarbitone and methohexitone. ${ }^{14}$

Since barbiturates interfere with adenyl cyclase activity in a variety of tissues including myocardial membrane preparations, we investigated the physiological importance of inhibition of the adenyl cyclase cascade in contributing to the myocardial depression by thiopentone.

\section{Methods}

Determination of thiopentone dose-response curves After approval by the University of Texas Medical Branch Animal Care and Use Committee, 200-250 g Wistar rats were sacrificed under halothane anaesthesia followed by quick removal of the heart. The left atrium was excised and placed in warmed $\left(37^{\circ} \mathrm{C}\right) \mathrm{Kreb}$ 's solution (composition in millimolar: $\mathrm{NaCl} \mathrm{118;} \mathrm{KCl} 4.6 ; \mathrm{MgSO}_{4} 4.9$; $\mathrm{CaCl}_{2}$ 2.5; glucose 11; $\mathrm{NaH}_{2} \mathrm{PO}_{4} 1.2 ; \mathrm{NaHCO}_{3} 25$ ) bubbled with $95 \% \mathrm{O}_{2}, 5 \% \mathrm{CO}_{2}$. The muscles were mounted to a force transducer (Grass, model FT03, Quincy, MA, USA) and $1.0 \mathrm{~g}$ base tension was applied. Contractions were induced with an electric stimulator (Grass model S88) at $1.0 \mathrm{~Hz}(1.0 \mathrm{~ms}$ squarewave bursts of $5.0 \mathrm{~V}$ ) and peak tension was displayed and measured on a polygraph (Gould Electronics, model 2400 , Cleveland, OH, USA). The atria were allowed to stabilize for $60 \mathrm{~min}$ before experiments began. Baseline contractions remained stable throughout the experimental period.

External field stimulation of isolated cardiac muscle has been shown to cause release of neurotransmitters from peripheral nerve terminals. ${ }^{15}$ Because barbiturates can inhibit release of neurotransmitters from peripheral autonomic nerves, ${ }^{16}$ maximal doses of atropine $\left(10^{-6} \mathrm{M}\right)$ were added to the bath to avoid confounding the results with this effect. For the same reason, maximal doses of isoprenaline $\left(10^{-6} \mathrm{M}\right)$ were used. Preparations initially were exposed to atropine $\left(10^{-6} \mathrm{M}\right)$ and allowed to stabilize. Isoprenaline $\left(10^{-6} \mathrm{M}\right)$ or dibutyryl-cAMP $\left(10^{-3}\right.$ $M)$ was then added in the continued presence of atropine. After the muscles had re-equilibrated, dose-response curves were obtained with cumulative doses of thiopentone. Thiopentone was then washed, with all preparations recovering to within $90 \%$ of the tension before adding the barbiturate. Similar dose-response curves were ob- tained using maximal doses of forskolin $\left(10^{-5} \mathrm{M}\right)$. Only one drug was tested on each preparation.

\section{Statistics}

Results are expressed as means $\pm \mathrm{SEM} ; P$ values were determined using two-tailed Student's $t$ test, with $P<$ 0.05 considered statistically significant.

\section{Drugs}

Thiopentone was obtained from Abbott Laboratories (North Chicago, IL). All other chemicals and reagents were obtained from Sigma (St. Louis, MO).

\section{Results}

Addition of atropine $\left(10^{-6} \mathrm{M}\right)$ to isolated contracting atria caused a small positive inotropic response (peak tension increased to $115 \pm 3.5 \%$ of control values, $P<0.05$ ). The addition of maximal doses of isoprenaline $\left(10^{-6} \mathrm{M}\right)$ to the bath increased contractile tension to $303 \pm 14 \%$ of initial tension, which was not different from the increase in tension by maximal stimulation with $10^{-3} \mathrm{M}$ dibutyryl cAMP (tension increased to $295 \pm 11 \%$ of initial tension). The dose-response curve (Figure 1) for thiopentone was shifted to the right in preparations treated with dibutyryl cAMP.

The increase in twitch tension by $10^{-5} \mathrm{M}$ forskolin (337 $\pm 41 \%$ of initial tension) was not different from stimulation with isoprenaline. The depression by thiopentone in these preparations was not different from that observed in isoprenaline-stimulated atria (Figure 2).

\section{Discussion}

The results of this study demonstrate that myocardial depression by thiopentone is attenuated in atria stimulated with dibutyryl cAMP when compared to preparations treated with the beta-adrenergic agonist isoprenaline. The myocardial depression induced by thiopentone in forskolin-treated muscle was not different from the depression in atria stimulated with isoprenaline.

Previous work has shown that the activity of adenyl cyclase from membrane preparations of various tissues can be inhibited by barbiturates. ${ }^{9-12}$ Only two studies have examined the influence of barbiturates on myocardial adenyl cyclase. Weinryb et al. ${ }^{9}$ found that the activity of adenyl cyclase from guinea pig ventricular homogenates was decreased in the presence of brominated barbiturates, and Khatter et al. ${ }^{10}$ showed that high doses of pentobarbitone inhibit adenyl cyclase activity of rat sarcolemmal preparations. An important limitation of these two studies is that inhibition of adenyl cyclase activity by barbiturates in tissue homogenates may not have a physiological consequence in intact muscle. We performed this study using intact muscle to clarify the im- 


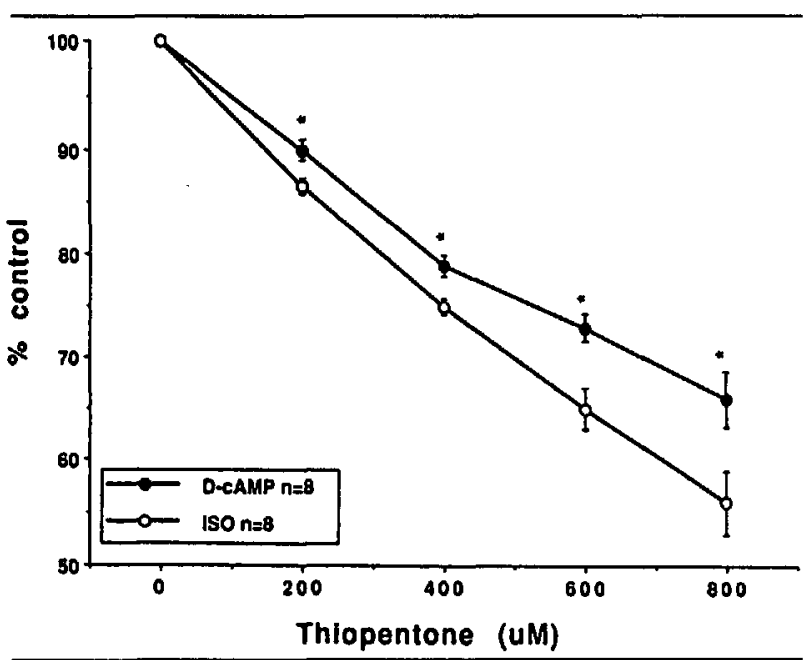

FIGURE I Dose-response curves to thiopentone in the presence of maximal concentrations of isoprenaline (ISO, $10^{-6} \mathrm{M}$ ) or dibutyrylcAMP (D-cAMP, $10^{-3} \mathrm{M}$ ). All experiments were performed in the presence of atropine $\left(10^{-6} \mathrm{M}\right)$. Data are expressed as a percentage of the contractile tension before thiopentone was administered. ${ }^{*} P<0.05$ between ISO and D-AMP groups.

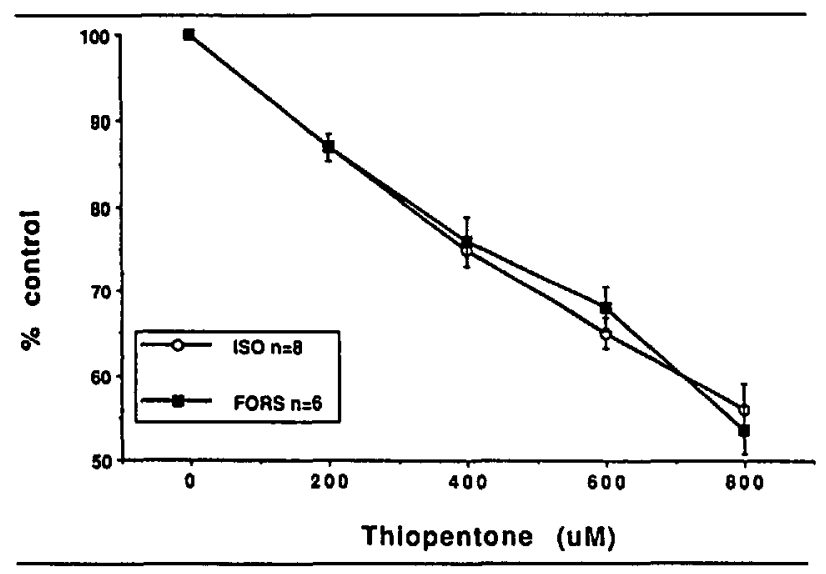

FIGURE 2 Dose-response curves to thiopentone in the presence of maximal concentrations of isoprenaline (ISO, $10^{-6} \mathrm{M}$ ) or forskolin (FORS, $10^{-5} \mathrm{M}$ ). All experiments were performed in the presence of atropine $\left(10^{-6} \mathrm{M}\right)$. Data are expressed as a percentage of the contractile tension before thiopentone was administered. There was no difference in the dose-response curves.

portance of inhibition of the adenyl cyclase cascade in contributing to myocardial depression by thiopentone.

The right-ward shift in the thiopentone dose-response curve in preparations treated with dibutyryl-cAMP compared with isoprenaline-stimulated atria indicates that inhibition of the adenyl cyclase cascade by thiopentone has physiological importance in cardiac muscle. These results are supported by other studies that have shown that barbiturates inhibit adenyl cyclase mediated responses in intact cells. ${ }^{13,14}$ However, most of the depression in con- tractility by thiopentone is not related to alterations of adenyl cyclase function.

Thiopentone could potentially inhibit the betaadrenergic system at multiple sites: (1) direct blockade of beta-adrenergic receptors, (2) interference with the coupling of beta-adrenergic receptors to adenyl cyclase either by alteration of membrane mechanics or $G$ protein function, (3) interference with the activation of adenyl cyclase by $G_{s}$ or other activators, (4) direct inhibition of adenyl cyclase activity, (5) inhibition of pathways activated by adenyl cyclase, or (6) acceleration of the degradation of cAMP. Forskolin causes a positive inotropic effect by directly activating adenyl cyclase. Since the dose-response curves to thiopentone were identical in forskolin-treated and isoprenaline-stimulated preparations, direct blockade of beta-adrenergic receptors is an unlikely mechanism that thiopentone decreases contractility. Barbiturates have been shown to directly inhibit adenyl cyclase activity in rat brain, probably by interfering with the activation of adenyl cyclase by the $\mathrm{G}$ protein, $\mathrm{N}_{\mathrm{s}}{ }^{11}$ Direct inhibition of myocardial adenyl cyclase or interference with the activation of adenyl cyclase by $G_{s}$ or forskolin are possible mechanisms that thiopentone could attenuate myocardial beta-adrenergic responses. Alternatively, accelerated degradation of CAMP or inhibition of pathways activated by cAMP may also contribute to the reduction of myocardial contractility by thiopentone. It is not possible to determine the exact site or sites that thiopentone inhibits the adenyl cyclase cascade from the results of this study; however, beta-adrenergic receptor blockade is an unlikely mechanism.

Since we performed this work in isolated tissue, inhibition of adenyl cyclase activity by thiopentone may have greater or lesser importance in whole animals and human patients. Clinical experience has shown that patients who are highly dependent on sympathetic tone (and therefore adenyl cyclase activity) to maintain cardiovascular stability tend to have exaggerated depressive responses to thiopentone. It is possible that inhibition of adenyl cyclase activity may be an important factor in mediating the cardiovascular collapse that is seen with administration of thiopentone in such patients.

In conclusion, our results demonstrate that part of the myocardial depression induced by thiopentone is secondary to inhibition of the adenyl cyclase cascade. However, other mechanisms are also involved in mediating thiopentone negative inotropy. Inhibition of adenyl cyclase may be an important mechanism that thiopentone causes an exaggerated cardiovascular depression in patients with high sympathetic tone.

\section{References}

1 Ikemoto $Y$. Reduction by thiopental of the slow-channel- 
mediated action potential of canine papillary muscle. Pflugers Arch 1977; 372: 285-6.

2 Ikemoto $Y$, Yatani A, Arimura $H$, Yoshitake $J$. Reduction of the slow inward current of isolated rat ventricular cells by thiamylal and halothane. Acta Anaesthesiol Scand 1985; 29: 583-6.

3 Gilat E, Rubinstein I, Binah $O$. Effect of sodium pentobarbital on the transmembrane action potential and the slow inward current of guinea pig ventricular myocytes. J Cardiovasc Pharmacol 1987; 10: 485-8.

4 Ebert TJ, Kanitz DD, Kampine JP. Inhibition of sympathetic neural outflow during thiopental anesthesia in humans. Anesth Analg 1990; 71: 319-26.

5 Nayler WG, Szeto J. Effect of sodium pentobarbital on calcium in mammalian heart muscle. Am J Physiol 1972; 222: 339-44.

6 Lain RF, Hess $M L$, Gertz EW, Briggs FN. Calcium uptake activity of canine myocardial sarcoplasmic reticulum in the presence of anesthetic agents. Circ Res 1968; 23: 597-604.

7 Drummond GI, Severson DL. Cyclic nucleotides and cardiac function. Circ Res 1979; 44: 145-53.

8 Thurston TA, Glusman S. Halothane myocardial depression: interactions with the adenyl cyclase system. Anesth Analg 1993; 76: 63-8.

9 Weinryb I, Michel IM, Alicino JF, Hess SM. Effects of barbiturate derivatives, sulfhydryl reagents, and oxidizing agents on the activity of adenyl cyclase from guinea pig heart and lung. Arch Biochem Biphys 1971; 146: 591-6.

10 Khatter JC, Hoeschen RJ, Dhalla NS. Effects of sodium pentobarbital on rat heart sarcolemma. Research Communications in Chemical Pathology and Pharmacology 1979; 24: $57-66$.

11 Dan'ura T, Kurokawa T, Yamashita A, Higashi K, Ishibashi $S$. Inhibition of brain adenylate cyclase by barbiturates through the effect on the interaction between guanine nucleotide-binding stimulatory regulatory protein and catalitic unit. Journal of Pharmacobio Dynamics 1987; 10: 98-103.

12 Dan'ura T, Kurokawa T, Yamashita A, Ishibashi S. Effective inhibition by pentobarbital of forskolin-stimulated adenyl cyclase activity in rat brain. Chem Pharm Bull (Tokyo) 1989; 37: 3142-4.

13 Masssart C. Le Tellier C, Mallédant Y, Leclech G, Nicol $M$. Modulation of the functional properties of human thyrocytes in monolayer of follicle culture: effects of some anaesthetic drugs. J Mol Endocrinol 1991; 7: 57-62.

14 Levine $S D$, Weber $H$, Schlondorff $D$. Inhibition of adenyl cyclase by general anesthestics in toad urinary bladder. Am J Physiol 1979; 237: F372-F378.

15 Blinks $J F$. Field stimulation as a means of effecting the graded release of autonomic transmitters in isolated heart muscle. J Pharmacol Exp Ther 1966; 151: 221-35.
16 Lindmar $R$, Löffelholz $K$, Weide $W$. Inhibition by pentobarbital of the acetylcholine release from the postganglionic parasympathetic neuron of the heart. J Pharmacol Exp Ther 1979; 210: 166-73. 